\title{
Perkembangan dan Prospek Sel Fotovoltaik Organik: Sebuah Telaah Ilmiah
}

\author{
Lukas B. Setyawan \\ Program Studi Teknik Elektro, \\ Fakultas Teknik Elektronika dan Komputer, \\ Universitas Kristen Satya Wacana, Salatiga \\ lukas.setyawan@staff.uksw.edu
}

\begin{abstract}
Ringkasan
Perkembangan teknologi OPV sangat menjanjikan sebagai sumber energi terbarukan dalam upaya mengurangi ketergantungan terhadap energi bahan bakar berasal dari fosil. Hal ini diperkuat karena ongkos fabrikasi perangkat fotovoltaik menggunakan material organik lebih murah dibandingkan dengan perangkat menggunakan material non-organik. Telaah ini membahas perkembangan organic photovoltaic cell (OPV) dari generasi pertama, kedua, dan ketiga. Berikutnya dibahas cara kerja OPV dan macam-macam OPV, seperti dye-sensitized solar cell (DSSC), double layer cell, bulk heterojunction cell, dan perovskite solar cell (PSC). Terakhir dibahas mengenai prospek yang dimiliki OPV. Dari perkembangan OPV terlihat bahwa efisiensi pada generasi pertama sebesar $6 \%$. Efisiensi generasi kedua $17 \%$. Sedangkan efisiensi generasi ketiga paling tinggi yaitu sekitar $26 \%$. Kelemahan OPV adalah efisiensinya rendah dan umur pakainya singkat. Sifat OPV ringan dan lentur sehingga penerapannya lebih luas.

Kata kunci: organic photovoltaic cell dye-sensitized solar cell, bulk heterojunction cell, perovskite solar cell
\end{abstract}

\section{Pendahuluan}

Sel Fotovoltaik Organik atau OPV (Organic Photovoltaic Cell) sering disebut sebagai sel surya (Solar Cell) adalah sel fotovoltaik yang menggunakan material organik sebagai penyusunnya. Proses penyerapan cahaya dan pengiriman muatan dilakukan oleh material organik. Kelemahan sel OPV dibanding sel surya inorganik adalah efisiensinya rendah dan umur pakainya singkat. Keuntungan sel OPV adalah biaya pembuatannya murah sehingga memungkinkan untuk pemakaian dalam jumlah besar. Karena sifat sel OPV ringan dan lentur maka aplikasi sel OPV lebih luas dibanding sel surya inorganik. Sel OPV bahkan mampu digunakan untuk kebutuhan yang tidak dapat dipenuhi oleh sel surya inorganik.

\section{Solar Cell atau Organic Photovoltaic Cell (OPV)}

Contoh solar cell (sel surya) adalah devais semikonduktor sambungan p-n yang mengubah energi matahari (sinar matahari) menjadi arus listrik melalui efek fotovoltaik. Sel surya akan mengalami proses fotovoltaik tidak perduli sumber cahaya apakah berasal dari sinar matahari atau cahaya lain. Cara kerja sel surya umumnya melalui tiga langkah berikut:

1. Absorpsi cahaya, membangkitkan terjadinya pasangan elektron-hole (exciton). 
2. Pemisahan exciton menjadi elektron dan hole sebagai pembawa muatan bebas.

3. Pembawa muatan yang sudah terpisah ini diangkut menuju anode dan katode dari sel surya, kemudian pembawa muatan tersebut diteruskan ke sirkit eksternal.

\section{Perkembangan Sel Surya}

Kemajuan teknologi sel surya ditujukan untuk menghasilkan sel surya yang murah, memiliki efisiensi tinggi dan berumur panjang yang paling berguna untuk menggantikan pembangkitan energi dari bahan bakar fosil. Penelitian terus dilakukan dalam teknologi fotovoltaik yang mengarah ke penemuan material baru dan cara baru dalam fabrikasi sel surya. Sel surya dikelompokkan menjadi tiga kelompok besar atau generasi berdasarkan urutan kemunculannya.

\subsection{Generasi Pertama}

Pada kategori ini sel surya umumnya terbuat dari wafer silikon. Bell Laboratories membangun sel surya silikon pertama kali pada tahun 1954, dengan efisiensi $6 \%$. Sejak itu penelitian untuk meningkatkan efisiensi dan memperkecil biaya pembuatan sel surya berkembang dengan cepat. Sel surya silikon paling banyak digunakan sebagai sel surya karena paling efisien sebagai devais fotovoltaik dalam bentuk sel kristalin tunggal. Selain itu silikon adalah unsur yang paling banyak tersedia di bumi, nomor dua setelah oksigen. Sel surya tipe ini paling sering digunakan dilaporkan memiliki efisiensi sel (sel kristal tunggal) sebesar $\sim 28 \%$. Ada tiga tipe silikon yang digunakan pada generasi ini, yaitu: single crystalline silicon (c-Si), multicrystalline silicon, dan amorphous silicon (a-Si). Kemajuan teknologi sel surya ditujukan untuk menghasilkan sel surya yang murah, Karena c-Si mahal dan biaya fabrikasinya besar maka hal ini mendorong penelitian menuju generasi berikutnya yaitu thin film solar cell. [1,2]

\subsection{Generasi Kedua}

Sel surya pada generasi ini dikenal sebagai thin film solar cell. Bahan thin film menjadi fokus penelitian yang intensif dalam upaya memperkecil ongkos fabrikasi menggunakan teknologi dengan bahan dasar Si dan untuk meningkatkan utilisasi material. Pada generasi kedua ini material dibuat agar ongkos produksi sel surya makin murah tanpa mempengaruhi keluaran energi yang dihasilkan. Tiga tipe material yang sering digunakan adalah hydrogenated amorphous silicon (a-Si:H), cadmium telluride (CdTe) juga copper indium diselenide (CuInSe2) dan campuran sejenis seperti Copper Indium Gallium diselenide CuInxGa1-xSe2 (CIGS). Efisiensi tertinggi sel tunggal thin film untuk CIGS sebesar 20\% dan untuk CdTe sebesar 17\%. Meski thin film solar cell ini memiliki keunggulan dibanding sel surya generasi pertama karena lebih murah dan efisiensinya lebih baik tetapi terdapat beberapa kekurangan. Sebagian besar material penyusun sel terbuat dari material yang mulai jarang dan makin mahal (indium) atau sangat beracun (cadmium). Untuk memproduksi secara masal diperlukan fasilitas baru sehingga akan memperbesar ongkos produksi. Hal ini memicu tumbuhnya generasi berikutnya. $[1,2]$

\subsection{Generasi Ketiga}

Sel surya pada generasi ini menerapkan konsep baru pada proses pembentukannya. Konsep baru ini merupakan solusi mengatasi kendala utama pada sel surya generasi pertama dan kedua, yaitu ongkos terlalu mahal pada generasi pertama dan sifat racun material yang digunakan dan ketersediaan material yang terbatas pada generasi kedua. 
Pada generasi baru ini mencakup Organic/polymer dan dye-sensitized solar cell. Teknologi Organic photovoltaic solar cell (OPV) memanfaatkan polimer yang lebih murah sebagai material pengganti semikonduktor inorganik (silikon, CdTe, dan CIGS). Sel surya generasi ketiga ini paling murah dibanding semua sel surya generasi sebelumnya. Efisiensi yang diperoleh dari sel tunggal dye-sensitized sebesar 11\% dan sel tunggal polimer sebesar $8 \%$. Hal ini menunjukkan bahwa efisiensi yang diperoleh dari sel surya organik secara umum sangat rendah. Fotovoltaik organik secara teknologi belum matang dan aplikasinya yang cukup luas dibatasi adanya masalah ketidakstabilan yang berkaitan dengan terjadinya penurunan kualitas pada lingkungan yang berbeda. Dengan demikian teknologi OPV dan dye-sensitized belum mampu untuk menjadikan sel surya tersebut memiliki daya saing di pasar komersial.

Upaya tak kenal lelah dari para peneliti dalam bidang fotovoltaik melahirkan sel surya tipe baru yaitu sel surya hibrida organik-inorganik dikenal dengan nama perovskite yang ditemukan oleh Miyasaka dan kawan-kawan pada tahun 2006. Material baru ini dilaporkan memiliki efisiensi tertinggi sebesar $\sim 19,3 \%$. Teknologi sel surya hibrida seperti sel surya perovskite disebut demikian karena lapisan fotoaktif terbuat dari material organometalik. [1, 2]

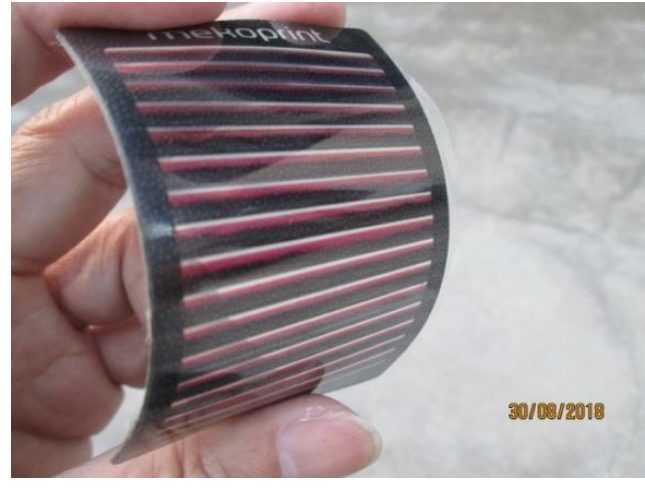

Gambar 1. OPV

\section{Prinsip Kerja Organic Solar Cell (OSC)}

Perbedaan utama sel surya organik dari sel surya inorganik adalah foton yang diterima diserap oleh material organik sehingga terbentuk pasangan elektron-hole yaitu exciton. Diperlukan energi untuk memisahkan exciton menjadi pasangan elektron dan hole bebas. Pemisahan ini dapat terjadi berkat gabungan dua material yang memiliki energi potensial berbeda yang menimbulkan medan elektrik yang dibutuhkan untuk memecah ikatan elektron-hole. Material yang memberikan elektron pada proses pemisahan exciton disebut donor, ditandai dengan seberapa tinggi level LUMO (lowest unoccupied molecular orbital ekivalen dengan pita konduksi). Sedangkan material yang menerima elektron ketika terjadi pemisahan exciton disebut akseptor, ditandai dengan seberapa rendah level HOMO (highest occupied molecular orbital ekivalen dengan pita valensi).

Prinsip kerja dasar sel surya organik, digambarkan oleh Gambar 2, adalah sebagai berikut:

1. Foton dengan energi Epн $>$ EGAP diserap oleh lapisan aktif membentuk terjadinya exciton.

2. Exciton akan menyebar (dengan jangkauan beberapa puluh nanometer sebelum terjadi rekombinasi) hingga mencapai perbatasan donor-akseptor. 
3. Exciton terpisah pada perbatasan donor-akseptor dan membentuk dua pembawa muatan bebas, satu positif dan satu negatif (disebut juga dengan polaron).

4. Pembawa muatan mampu menyebrangi material karena adanya dorongan energi potensial kimia menuju masing-masing elektrode.

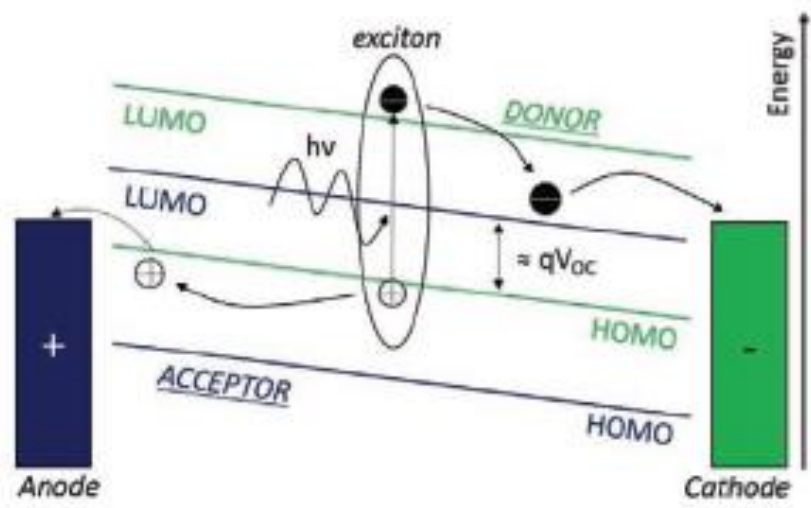

Gambar 2. Foton dengan energi hv membentuk exciton yang terpisah menjadi kutub positif dan negatif. Kemudian muatan dikumpulkan pada masing-masing elektrode. [2]

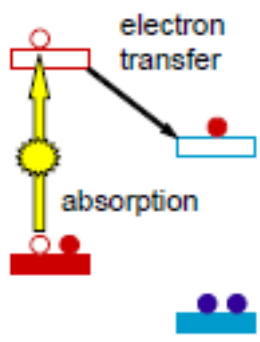

donor acceptor

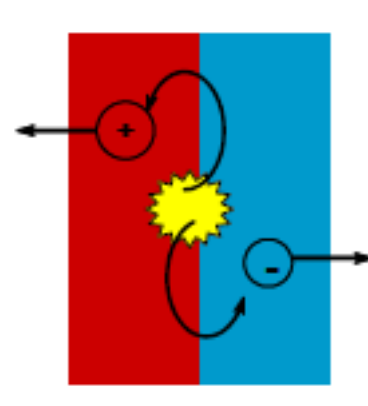

exciton dissociation into + and - charge carriers

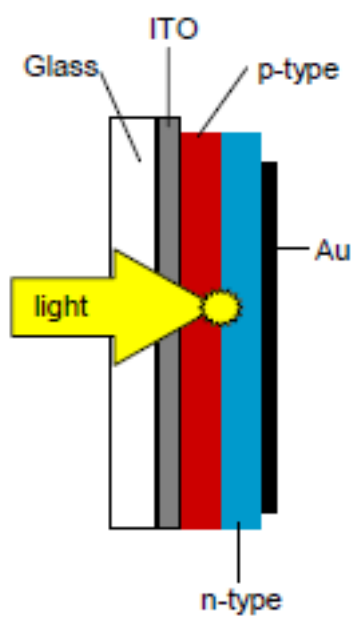

Gambar 3. Gambar skema prinsip kerja organic photovoltaic cell (OPV). [3]

Penyinaran donor (warna merah) menembus electrode tembus pandang (ITO) membawa donor ke keadaan fotoeksitasi, dalam keadaan ini elektron didorong dari level highest occupied molecular orbital (HOMO) menuju level lowest unoccupied molecular orbital (LUMO). Selanjutnya elektron yang telah tereksitasi ini masuk ke level LUMO akseptor (warna biru) sehingga akseptor kelebihan elektron dan meninggalkan hole pada donor. Muatan yang dibangkitkan ini kemudian dikirimkan dan dikumpulkan pada elektrode berlawanan. Proses pembangkitan muatan yang sama juga terjadi saat akseptor terkena sinar.

Agar sel fotovoltaik bekerja maka material pekacahaya (donor dan akseptor) dijepitkan di antara dua elektrode metalik yang berbeda (salah satu adalah tembus pandang) untuk mengumpulkan muatan yang sudah terbangkit. Setelah reaksi transfer muatan berikutnya muatan tersebut bergerak menuju elektrode tanpa mengalami proses rekombinasi. Yang paling penting muatan yang terbangkitkan ini dapat menuju untai eksternal pada elektrode tanpa ada masalah sambungan. 
Jumlah foton yang mengenai sel surya yang diubah menjadi exciton kemudian dipisah dan dikumpulkan pada elektrode menentukan efisiensi kuantum dari sel surya. Perbandingan jumlah elektron yang terkumpul dibagi dengan jumlah foton yang masuk sesuai energi yang diberikan menentukan besarnya External Quantum Efficiency (EQE). Sedangkan perbandingan jumlah elektron yang terkumpul dibagi dengan jumlah foton yang diserap oleh lapisan aktif sesuai energi yang diberikan menentukan besarnya Internal Quantum Efficiency (IQE). [2]

$$
\begin{aligned}
& E Q E=\frac{\frac{n_{e}}{t}}{\frac{n_{f}}{t}} \\
& I Q E=\frac{\frac{n_{e}}{t}}{\frac{n_{f s}}{t}}
\end{aligned}
$$

$\mathrm{n}$ e $=$ jumlah elektron

$\mathrm{n}_{\mathrm{f}}=$ jumlah foton

$\mathrm{n}_{\mathrm{fs}}=$ jumlah foton yang diserap

$\mathrm{t}$ = waktu (s)

Perbandingan daya keluaran dibagi daya masukan adalah efisiensi konfersifoto $\eta$ disebut dengan Power Conversion Efficiency (PCE). Efisiensi tergantung pada arkitektur dari lapisan aktif yang menentukan probabilitas proses pemisahan exciton. [2]

\section{Macam-macam Sel Surya Organik}

\subsection{Dye-sensitized solar cell (DSSC)}

Pada DSSC pewarna organik diserapkan di atas permukaan semikonduktor inorganik dengan energi gap cukup besar sebagai penyerap cahaya dan untuk mendorong elektron yang tereksitasi menuju pita konduksi semikonduktor tersebut. Penelitian pada DSSC memperoleh kemajuan besar ketika Grätzel dan rekan kerjanya meningkatkan daerah persambungan antara donor organik dan akseptor inorganik menggunakan nanoporous titanium dioxide $\left(\mathrm{TiO}_{2}\right)$. Menggunakan ruthenium dye-sensitized nanocrystalline $\mathrm{TiO}_{2}\left(\mathrm{nc}^{\left.-\mathrm{TiO}_{2}\right)}\right.$ efisiensi konversi energi sel surya mencapai 10\% di bawah paparan sinar matahari. [3]

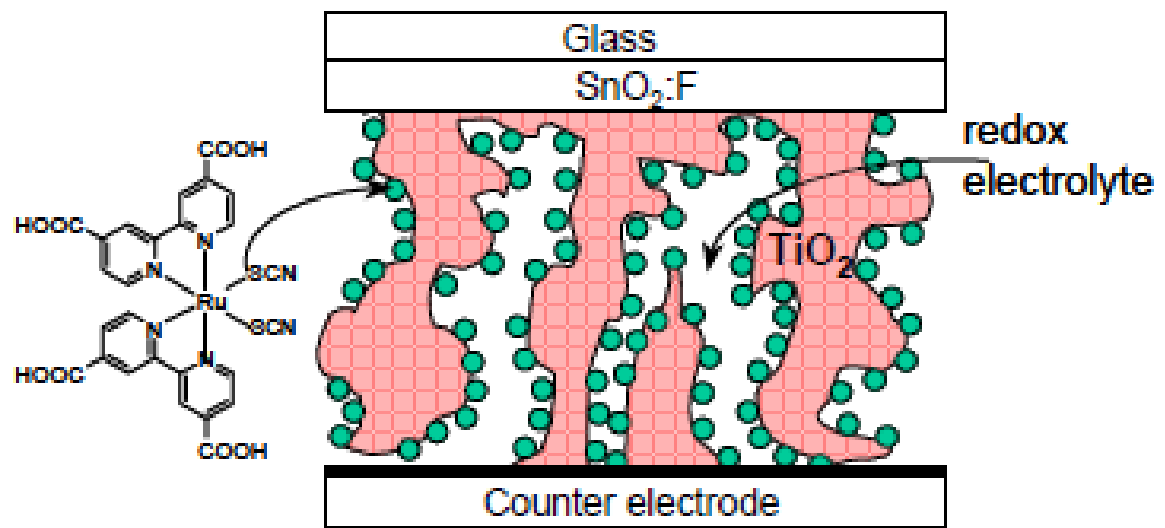

Gambar 4. Sel surya DSSC. [3] Setelah cahaya diserap oleh pewarna ruthenium kemudian elektron diteruskan menuju $\mathrm{TiO}_{2}$. Pewarna ini kemudian diturunkan oleh elektrolit redox I-/I3- sehingga elektrode lawan dari metal juga menurun. Dengan demikian muatan positif akan dikirimkan dari pewarna lewat elektrolit menuju elektrode metal. Elektron pada $\mathrm{TiO}_{2}$ diteruskan menuju elektrode fluorine doped tin oxide $\left(\mathrm{SnO}_{2}: \mathrm{F}\right)$. 


\subsection{Double Layer Cell}

Awal usaha untuk membuat sel surya dari unsur organik semua adalah dengan menyisipkan lapisan tunggal material organik di antara dua elektroda berbeda. Sifat fotovoltaik sel ini sangat tergantung pada sifat alam elektrode. Material yang ikatannya didope dalam jumlah besar menghasilkan efisiensi konversi daya sampai dengan 0,3\%. Pada tahun 1986 Tang melakukan terobosan dengan merealisasikan struktur lapisan ganda menggunakan semikonduktor organik tipe-p dan tipe-n. Dua lapis setebal $70 \mathrm{~nm}$ dibuat menggunakan copper phthalocyanine sebagai donor elektron, dan turunan perylene tetracarboxylic sebagai akseptor elektron. Material peka cahaya diletakkan di antara dua elektrode berbeda, yaitu indium tin oxide (ITO) sebagai pengumpul muatan positif dan perak (Ag) untuk mengumpulkan muatan negatif. Efisiensi konversi power sekitar $1 \%$. Hal terpenting pada konsep ini adalah efisiensi pembangkitan muatan tidak dipengaruhi besarnya tegangan bias. [3]

\subsection{Bulk Heterojunction Cell}

Pada proses penggabungan material penyumbang elektron (tipe-p) dan material penerima elektron (tipe-n) pada lapisan aktif sel surya harus diperhatikan agar exciton yang terbentuk pada salah satu material dapat menyebar menuju persambungan memungkinkan terjadi pemisahan muatan. Oleh karena exciton umurnya singkat dan mobilitasnya rendah maka jangkauan sebaran exciton pada semikonduktor organik terbatas hanya sekitar $\sim 10 \mathrm{~nm}$. Ini akan sangat berpengaruh pada penurunan tingkat pembangkitan muatan. Dimanapun pada lapisan aktif jarak ke persambungan harus dapat dijangkau oleh sebaran exciton. [3]

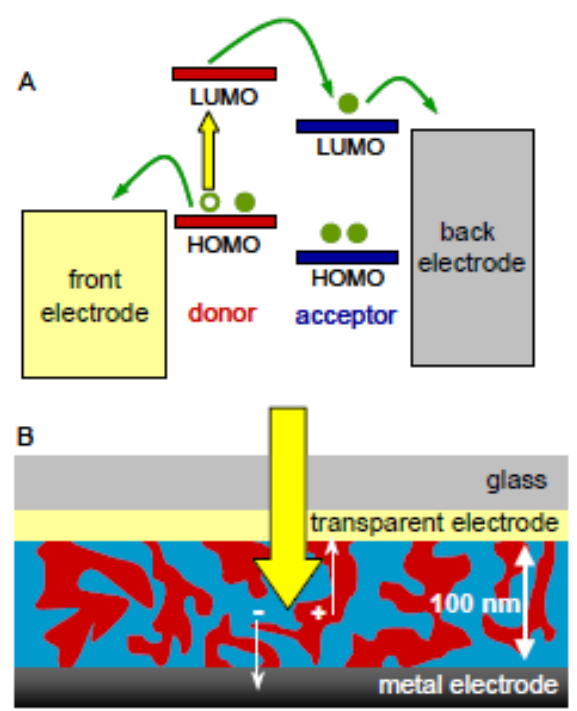

Gambar 5. Kosep bulk-heterojunction. [3] Setelah material peka cahaya menyerap sinar transfer muatan dapat berlangsung berkat pencampuran antara donor dan akseptor. Akibatnya muatan yang terbangkit diteruskan dan dikumpulkan pada elektrode.

\subsection{Perovskite Solar Cell (PSC)}

PSC termasuk sel surya fotovoltaik generasi ketiga. Sistem penyerapan cahaya oleh organometallic halide membuat efisiensi konversi daya lebih tinggi ditambah dengan material lebih murah. 


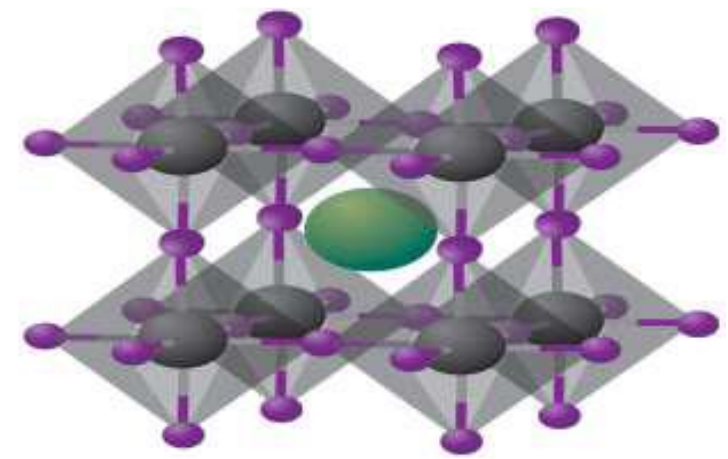

Gambar 6. Struktur kristal perovskite methylammonium lead halide (CH3NH3- $\mathrm{PbX} 3)$ [4]

Hasil penelitian akhir-akhir ini mencatat bahwa sel surya silikon tradisional memiliki efisiensi sebesar 25\% tetapi untuk memperoleh efisiensi setinggi itu sangat mahal biaya pembuatannya sehingga biasanya yang terpasang adalah sel surya dengan efisiensi sekitar 15\%. PSC dilaporkan memiliki efisiensi 26\% dengan keunggulan biaya produksi rendah dan karakteristiknya sangat stabil. Sedangkan teknologi thin film yang merupakan generasi kedua menghasilkan efisiensi 12-20\%.

\section{Prospek OPV}

Prospek OPV dibatasi oleh kendala yang dimiliki oleh OPV. Pada sel OPV ketika temperatur naik maka mobilitas muatan akan meningkat. Pada saat temperatur rendah pembawa muatan yang dibangkitkan karena pengaruh termal lebih sedikit sehingga tidak mudah dikirimkan dan akibatnya tanpa ada penyinaran arus yang mengalir menjadi kecil. [5]

Meski solar sel silikon saat ini masih mendominasi pasar tetapi dalam waktu dekat akan terjadi perubahan karena perkembangan OPV sangat cepat. Sel OPV terbuat dari polimer sebagai penyerap cahaya dan tidak menggunakan silikon. Karena itu biaya produksinya lebih murah. Energi yang dibutuhkan pada proses pembuatan OPV lebih sedikit dibanding proses pembuatan sel surya silikon sehingga proses pembuatan sel OPV lebih ramah lingkungan. [6]

Efisiensi OPV masih rendah sekitar 8,3\%. Dengan menggunakan nanoteknologi diharapkan terjadi kenaikan efisiensi setara dengan sel surya silikon. [5] [6] Selain efisiensinya rendah kelemahan Sel OPV adalah umurnya singkat. Sel OPV komersial memiliki umur operasional 5 tahun. [5]

Sifat sel OPV biaya pembuatannya murah, ringan, dan lentur tetapi efisiensinya lebih rendah dibanding sel surya inorganik. Karena sifatnya ringan dan lentur maka OPV cocok dipakai untuk beragam kegunaan, mulai perangkat catu ulang baterai laptop, ponsel, sampai ke penyedia daya untuk perangkat jinjing seperti ponsel dan pemutar MP3. [6]

Saat ini penerapan teknologi sel surya antara lain di bidang pembangkit listrik, sinar dan energi matahari diubah menjadi energi listrik. Di bidang kebutuhan energi listrik rumah tangga, dengan memasang panel surya di atas atap. Di bidang pemakaian komersial, energi dari matahari digunakan untuk memenuhi kebutuhan energi listrik perumahan atau gedung perkantoran. Di bidang sistem ventilasi, panel surya dimanfaatkan untuk mengoperasikan kipas angin di kamar mandi, plafon, dan lantai gedung untuk menghemat biaya pemakaian listrik. Di bidang lain pemakaian panel surya banyak digunakan untuk pemanas kolam renang, penerangan jalan, dan mobil listrik. [7] 


\section{Kesimpulan}

Saat ini perkembangan sel OPV berada pada generasi ketiga. Efisiensi pada generasi ketiga ini lebih tinggi dibanding generasi pertama dan generasi kedua. Kendala utama sel OPV adalah efisiensi dan umur pakainya. Sel OPV bekerja lebih baik pada temperatur tinggi karena mobilitas muatan meningkat ketika temperatur sel surya lebih tinggi.Karena sifatnya yang ringan dan lentur maka penerapan sel OPV lebih luas dan bisa diterapkan untuk kebutuhan yang tidak bisa dipenuhi oleh sel surya silikon. OPV generasi pertama masih memiliki efisiensi sebesar 6\%. Generasi kedua efisiensinya sekitar 17\%. Sedangkan generasi ketiga memiliki efisiensi sebesar $26 \%$. Penelitian secara intensif terus dilakukan untuk mendapatkan sel OPV dengan efisiensi yang lebih tinggi.

\section{Daftar Pustaka}

[1] Amu, Tochukwu Loreta, "Performance Optimization of Tin Halide Perovskite Solar Cells Via Numerical Simulation," Master of Science Thesis, Department of Theoretical Physics, African University of Science and Technology, Abuja, December 2012.

[2] Corazza, M., Gevorgyan, S., \& Krebs, F. C. (2016). Characterization of Organic Solar Cell Devices and their Interfaces under Degradation: Imaging, Electrical and Mechanical Methods. Risø, Roskilde: Department of Energy Conversion and Storage, Technical University of Denmark.

[3] René Janssen, "Introduction to Polymer Solar Cells," Departments of Chemical Engineering \& Chemistry and Applied Physics, Eindhoven University of Technology, The Netherlands.

[4] Supreeth A, Shreya Y S, "Perovskite Solar Cell: A Review," International Journal of Engineering Development and Research," Vol. 4, Issue 2, 2016. ISSN 2321-9939

[5] Azmira Jannat, Muhammad Foyazur Rahman, M. Saddam Hossain khan, "A Review Study of Organic Photovoltaic Cell," International Journal of Scientific \& Engineering Research," Vol. 4, Issue 1, January 2013. ISSN 2229-5518

[6] Askari. Mohammad Bagher, "Introduction to Organic Solar Cells." Sustainable Energy, vol. 2, no. 3 (2014): 85-90. doi: 10.12691/rse-2-3-2.

[7] Navneet Kour, Rajesh Mehra, "Recent Advances in Photovoltaic Technology based on Perovskite Solar Cell-A Review," International Research Journal of Engineering and Technology (IRJET)," Vol. 04 Issue 07, July 2017. e-ISSN 2395-0056 p-ISSN: 2395-0072 